\title{
JET PENETRATION IN SLAG AND METAL INTO BOF COLD MODEL*
}

\author{
Breno Totti Maia ${ }^{1}$ \\ Caio Nogueira Araújo Diniz ${ }^{2}$ \\ Gustavo Germano Pereira ${ }^{3}$ \\ Rafael Kajimoto Imagawa ${ }^{4}$ \\ Raissa Santos Salgado \\ Roberto Parreiras Tavares ${ }^{6}$
}

\begin{abstract}
In the present paper, a new energy balance equation was developed, considering the slag phase, in order to define the effects of jet penetration and determine a new value for the factor $K$. The factor $K$ measure the resistance to momentum transference between exit nozzle and metallic bath. The experiments were performed based on the same conditions of the article used as a comparison. The results showed the same behavior between the experiments and it was possible to determine a new value for the factor $\mathrm{K}$, which changed from the unit order for the metal phase system to hundredths order for the metal and slag phase systems. These results are considered unprecedented.
\end{abstract}

Keywords: BOF; Cold model; Jet penetration; Slag metal bath; Factor K.

1 Sócio da ABM; Engenheiro Metalurgista e Doutor Pesquisador da Lumar Metals, Belo Horizonte, MG, Brasil.

2 Aluno de Graduação do Curso de Engenharia Metalúrgica da UFMG, Belo Horizonte, MG, Brasil.

3 Aluno de Graduação do Curso de Engenharia Metalúrgica da UFMG, Belo Horizonte, MG, Brasil.

4 Aluno de Graduação do Curso de Engenharia Metalúrgica da UFMG, Belo Horizonte, MG, Brasil.

5 Aluno de Graduação do Curso de Engenharia Metalúrgica da UFMG, Belo Horizonte, MG, Brasil.

6 Sócio da ABM; Engenheiro Metalurgista; Professor Doutor do Departamento de Engenharia Metalúrgica da UFMG, Belo Horizonte, MG, Brasil. 


\section{INTRODUCTION}

Reactors that produce molten steel, such as BOF, EAF and others have a growing tendency for studies that allow defining the penetration depth of the air jet into the bath and the ability of moving this mass in order to maximize the gas efficiency and reduce the process time. The energy transference mechanism through mass transference has been known for a half century, however its use in practical applications and new developments using computational simulations have increase in the last 15 years. According to Szekely and Themelis ${ }^{[1]}$, at the point the gas reaches the liquid surface, a cavity is formed, the surface is unstable and oscillates in both lateral and vertical directions. Figure 1 represents the described phenomena.

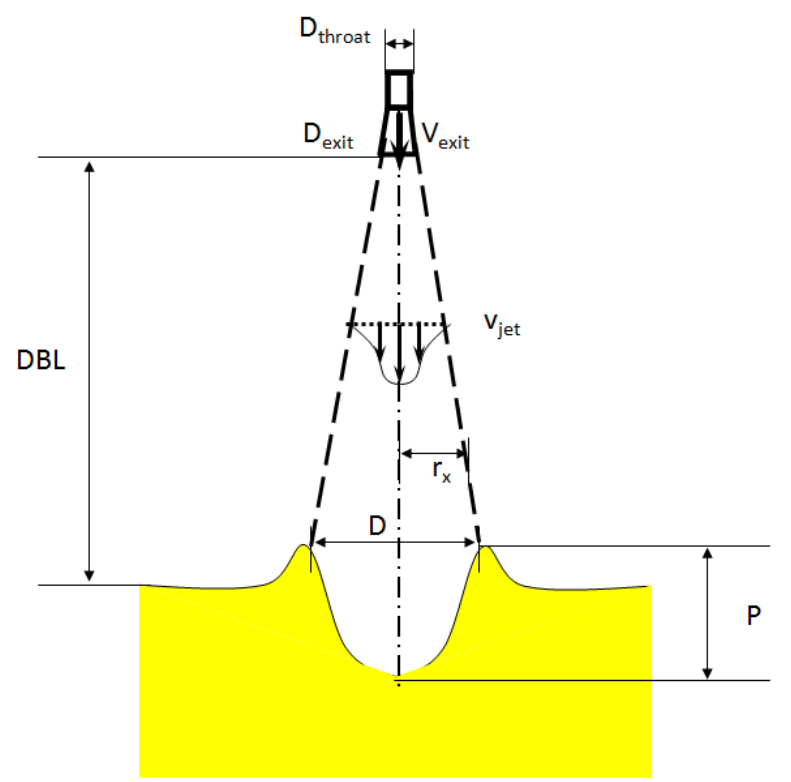

Figure 1 - Jet Penetration Model ${ }^{[1]}$.

The gas jet transfers momentum, generates the molten bath movement, and induces the elevation of the edges around the cavity. After reaching a specific cavity depth, a small ripple, which is formed in the outskirts, breaks into small droplets that are ejected to the environment and when returning, drag small gas bubbles. The cavity depth of the molten bath correlates with the jet momentum through an energy balance taken at the bottom of the cavity, according to the following equation: $\frac{1}{2} \times \rho_{\text {gas }} \times V_{\text {jet }}{ }^{2}=g \times \rho_{\text {steel }} \times P+\frac{2 \times \sigma}{r_{x}}$

Equation 1

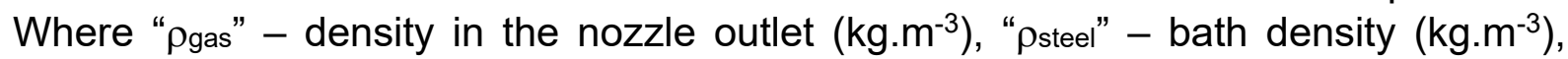
" $\vee_{\text {jet" }}$ - jet velocity under the nozzle outlet along the jet axis $\left(\mathrm{m} . \mathrm{s}^{-1}\right)$, " $\mathrm{g}$ " - gravitational acceleration $\left(\mathrm{m} \cdot \mathrm{s}^{-2}\right)$, "P" - cavity penetration in the bath $(\mathrm{m})$, "rx" - radius of cavity in the bath at the stagnant point $(m)$ e " $\sigma$ " - surface tension $\left(N \cdot m^{-1}\right)$.

Through a cold model, Meidani et al ${ }^{[2]}$ have realized studies for the vertical blow of a central single hole and auxiliary holes in order to define the BOF penetration according Equation 2.

$\frac{\pi}{2 \times K^{2}} \times\left(\frac{P}{D B L}\right) \times\left(1+\frac{P}{D B L}\right)^{2}=\frac{\left(\pi / 4 \times \rho_{\text {gas }} \times V_{\text {exit }}{ }^{2} \times D_{\text {exit }}{ }^{2}\right)}{\rho_{\text {steel }} \times g \times D B L^{3}}$

Where: "DBL" - Distance Bath Lance $(\mathrm{m})$, "Vexit" - Velocity at the nozzle outlet $(\mathrm{m} / \mathrm{s})$, "Dexit" - Outlet nozzle diameter, "K" - Empiric constant. 
Alam et $\left.a\right|^{[3]}$ developed a equation to determine jet penetration from single nozzle for EAF and introduced angle for injectors, like shown at equation 3 and figure 2.

$\frac{\pi}{2 \times K^{2}} \times\left(\frac{P}{H}\right) \times\left(1+\frac{p}{H \cos \theta}\right)^{2}=\frac{\left(\pi / 4 \times \rho_{\text {gas }} \times V_{\text {exit }}{ }^{2} \times D_{\text {exit }}{ }^{2}\right) \cos \theta}{\rho_{\text {steel }} \times g \times H^{3}}$

Equation 3

Where: " $\theta$ " - Nozzle angle with vertical

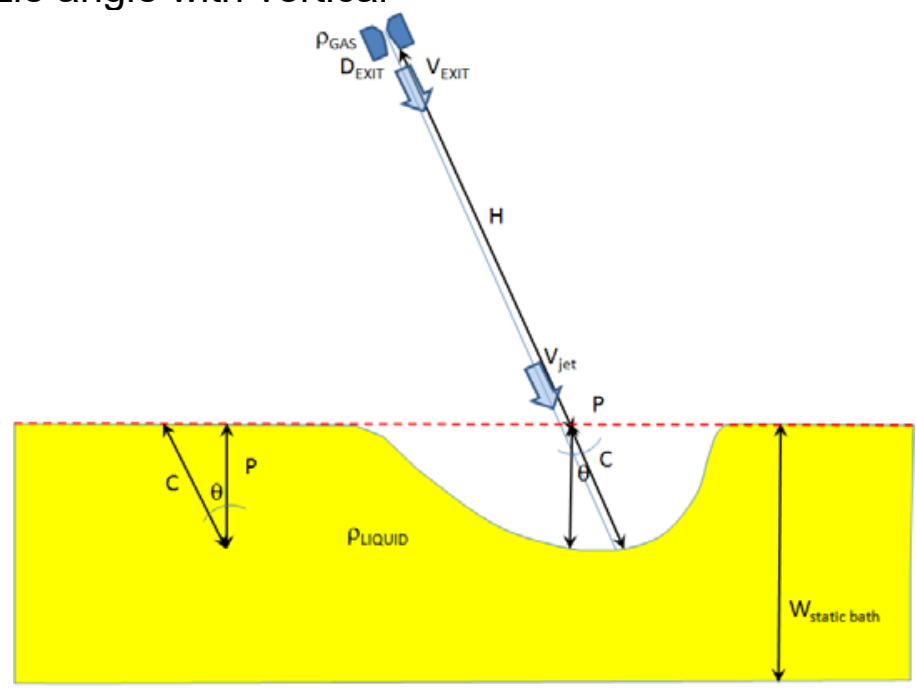

Figure 1- Shecmatic angle jet for EAF (Alam et al ${ }^{[3]}$ ).

Maia et al[4-6] considering multi nozzles that can be between 3 until 6 , introduced equation 4.

$\frac{2}{K^{2}} \frac{P}{D B L}\left(1+\frac{P}{D B L \times \cos \theta}\right)^{2}=\frac{\pi \times \rho_{G A S} \times V_{E X I T}^{2} \times D_{E X I T}^{2} \times \cos \theta \times n}{4 \times \rho_{\text {STEEL }} \times g \times D B L^{3}}$

Equation 4

Where: "n" - number of nozzles.

However, after Szekely and Themelis ${ }^{[1]}$, at all equations showed the surface tension was neglected. At equations showed above, slag layer was not considered. This parameters has strong influence at $\mathrm{K}$ factor as well to describe jet behavior between this two phases: metal and slag. The present paper has target to developed a equation that consider this parameters and can be used to practical adjustments during BOF blow.

\section{MATERIAIS E MÉTODOS}

For the development of the present study, were considered all the steps to get the equation developed by Szekely and Themelis [1] including the term of surface tension and considering the polyphase bath, consisting of slag and metal. The tuyeres were considered as a new element in experiment and are responsible for injection of gas, liquids and solids (the most part of processes just use inert gases) through the bottom of converter. The tuyeres are an important source of movement and bath homogenization. Figure 3 shows the jet penetration behavior into the polyphase static bath (slag and metal) and gas injection through the bottom of converter. 


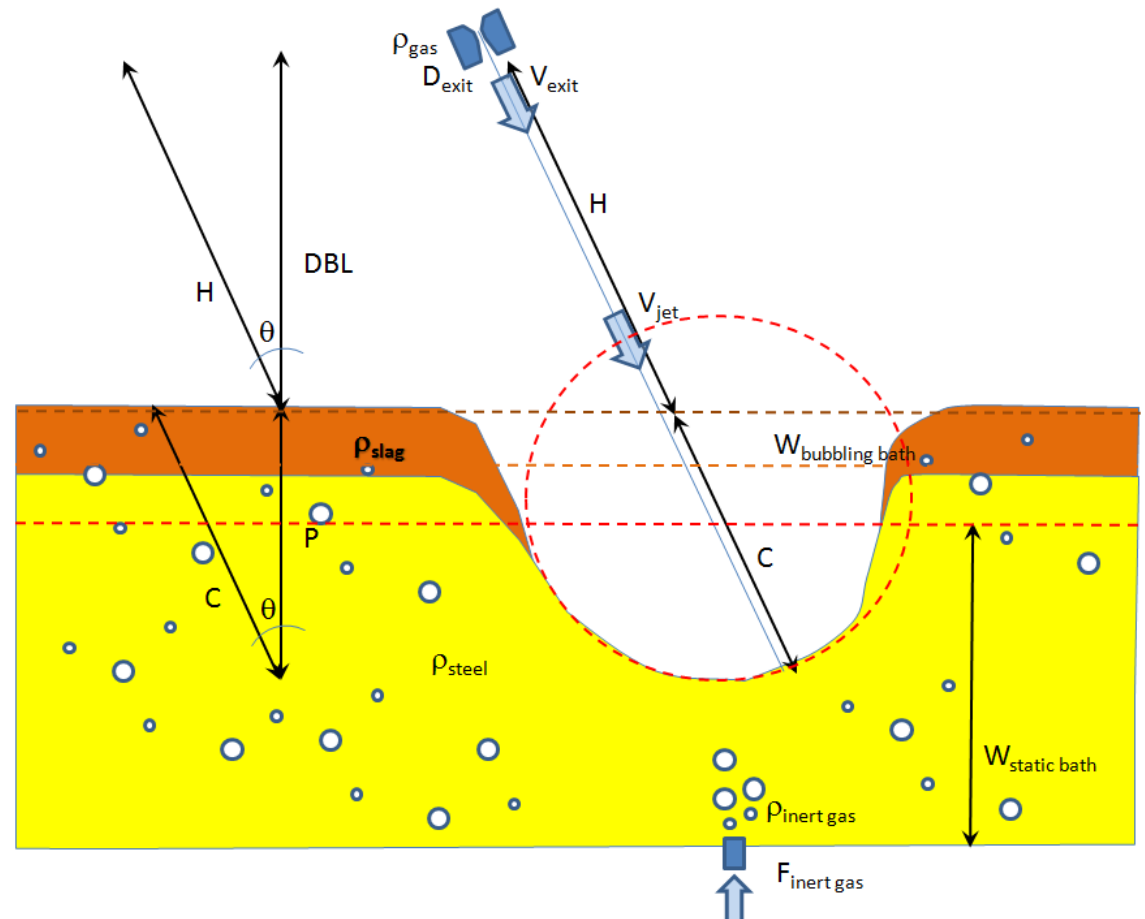

Figure 3 - Jet penetration behavior into the polyphase static bath (slag and metal) with gas injection through the bottom of converter.

Figure 3 shows the static bath ( $\mathrm{W}_{\text {static bath }}$ ) with bubbling gas, that is responsible for increasing the bath height, establishing a new level ( $\left.W_{\text {bubbling bath }}\right)$ which influences the jet penetration and the slag viscosity as well, as shown in equation 6.

$$
\begin{aligned}
\frac{1}{K^{2}} \times\left(\frac{\pi}{2} \times \frac{P}{(D B L+P)}\right) \times\left(1+\frac{1}{P^{2}} \times \frac{\cos \theta \times\left(\sigma_{\text {STEEL }}+\sigma_{\text {SLAG }}\right)}{\left(\rho_{\text {STEEL }}+\rho_{\text {SLAG }}\right) \times g}\right)= \\
\left(\frac{\pi}{4} \times \frac{\left(\rho_{\text {GAS }} \times{V_{\text {EXIT }}}^{2} \times D_{\text {EXIT }}{ }^{2} \times \cos \theta^{2} \times n\right)}{\left(\rho_{\text {STEEL }}+\rho_{\text {SLAG }}\right) \times g \times(D B L+P)^{3}}\right)
\end{aligned}
$$

Equation 4

Where "k" is an empirical constant, "DBL" - bath lance distance $(m)$, "P" - cavity penetration inside de bath $(\mathrm{m})$, " $\rho$ steel" - bath density $\left(\mathrm{kg} \cdot \mathrm{m}^{-3}\right)$, " $\rho$ slag" - slag density $\left(\mathrm{kg} \cdot \mathrm{m}^{-3}\right)$, " $\rho$ gas" - gas density $\left(\mathrm{kg} \cdot \mathrm{m}^{-3}\right)$, " $\sigma$ " - surface tension $\left(\mathrm{N} \cdot \mathrm{m}^{-1}\right)$, "Vexi" - exit velocity (m/s), "Dexit" - exit diameter, "g" - gravity acceleration $\left(\mathrm{m} . \mathrm{s}^{-2}\right)$, " $\theta$ " inclination angle and " $n$ " number of holes in the nozzle .

In equation 6, the density of the metal- slag mix is affected by the flow of gas injection in the bottom of converter. As higher is the gas injection, the metal-slag mix density is lower, causing more movement in the bath level. The $\mathrm{k}$ factor measure the momentum transfer resistance between nozzle exit and metallic bath. Those resistances can be related with the furnace ambient conditions, jet degradation by enhance, coalescence, emulsion and others. The calculation of density variation is shown in Figure 7.

$$
\left(\rho_{\text {STEEL }}+\rho_{\text {SLAG }}\right)=\frac{\left(W_{\text {INERTGAS }}+W_{\text {STATICBATH }}+W_{\text {SLAG }}\right)}{\left(F_{\text {INERTGAS }}+V_{\text {STATICBATH }}+V_{\text {SLAG }}\right)}
$$


Where: "W slag layer mass $(\mathrm{kg})$, "F INERTGAS" - inert gas injection flow $\left(\mathrm{m}^{3} / \mathrm{h}\right)$, "V $\mathrm{V}_{\text {STATICBATH" }}$ - static bath volume $\left(\mathrm{m}^{3}\right)$, "V $\mathrm{SLAG}$ " - slag layer volume $\left(\mathrm{m}^{3}\right)$.

Li et al [7] shows in Table 1 the comparison between parameters of industrial practice and cold model. The present work and the results achieved were used to compare with other parameters and results. Table 1 shows the parameters used to the development of this work and Li et al [7] works.

Table I - Comparison between parameters: industrial and cold model

\begin{tabular}{|c|c|c|c|c|c|c|}
\hline \multirow{2}{*}{ Parameters } & \multirow[b]{2}{*}{ Symbol } & \multirow[b]{2}{*}{ Unit } & \multicolumn{2}{|c|}{ Present Work } & \multicolumn{2}{|l|}{ Li et al [7] } \\
\hline & & & BOF & Cold Model & BOF & Cold Model \\
\hline Converter capacity & & $\mathrm{kg}$ & 220.000 & 64 & 150.000 & - \\
\hline Static bath height & $\mathrm{H}$ & $\mathrm{m}$ & 1,715 & 0,250 & 1,54 & 0,154 \\
\hline Converter diameter & Do & $\mathrm{m}$ & 5,716 & 0,688 & 5,685 & 0,5685 \\
\hline Slag layer height & $\mathrm{H}_{\text {slag }}$ & $\mathrm{m}$ & 0,46 & 0,024 & 0,17 & 0,017 \\
\hline Ratio slag/metal & - & & $5 / 41$ & $5 / 41$ & $6 / 25$ & $6 / 25$ \\
\hline Bath lance distance & $\mathrm{DBL}$ & $\mathrm{m}$ & 2,11 & 0,38 & 1,2 a 2,2 & 0,12 a 0,22 \\
\hline Nozzle exit diameter & Dexit & $\mathrm{m}$ & 0,053 & 0,0033 & 0,0434 & 0,00434 \\
\hline Critical nozzle exit diameter & $D_{\text {throat }}$ & $\mathrm{m}$ & 0,042 & 0,0026 & 0,03 & 0,003 \\
\hline Number of holes & $\mathrm{n}$ & \# & 5 & $5-6$ & 6 & 6 \\
\hline Vertical angle nozzle & $\theta$ & & 14 & $14-17,5$ & 17,5 & 17,5 \\
\hline Mach number & $\mathrm{Ma}$ & - & 2,02 & 0,80 & 2,25 & - \\
\hline Stagnant temperature & $\mathrm{T}_{\mathrm{o}}$ & $\mathrm{K}$ & 298 & 298 & 308 & 300 \\
\hline Metal bath temperature & $T_{\text {bath }}$ & $\mathrm{K}$ & 1640 & 298 & 1640 & 293 \\
\hline Stagnant pressure & $P_{0}$ & $\mathrm{~Pa}$ & 1.189 .748 & 835.757 & 1.171 .658 & - \\
\hline Ambient BOF pressure & $P_{\text {bath }}$ & $\mathrm{Pa}$ & 101.325 & 101.325 & 101.325 & 101.325 \\
\hline Oxygen flow & $Q$ & $\mathrm{~m}^{3} / \mathrm{h}$ & 40.054 & 36 & 30.283 & 39,5 \\
\hline Metal density & $\rho_{\text {steel }}$ & $\mathrm{Kg} / \mathrm{m}^{3}$ & 6930 & 1000 & 7000 & 1000 \\
\hline Metal dynamic viscosity & Hsteel & Pa.s & 0,0055 & 0,001 & 0,0065 & 0,001 \\
\hline Metal surface tension & $\sigma_{\text {steel }}$ & $\mathrm{N} / \mathrm{m}$ & 1,15 & 0,0728 & 1,6 & 0,073 \\
\hline Slag density & $\rho_{\text {slag }}$ & $\mathrm{Kg} / \mathrm{m}^{3}$ & 2300 & 865 & 3.500 & 925 \\
\hline Slag dynamic viscosity & $\mu_{\text {slag }}$ & Pa.s & 0,0835 & 0,055 & 0,1 & 0,015 \\
\hline Slag surface tension & $\sigma_{\text {slag }}$ & $\mathrm{N} / \mathrm{m}$ & 0,30 & 0,05 & 0,4 & 0,0029 \\
\hline Gas density & $\rho_{0}$ & $\mathrm{Kg} / \mathrm{m}^{3}$ & 15,37 & 9,77 & 14,64 & 1,16 \\
\hline Gas dynamic viscosity & $\mu_{0}$ & Pa.s & $2,03 \times 10^{-5}$ & $1,78 \times 10^{-5}$ & $1,9 \times 10^{-5}$ & $1,75 \times 10^{-5}$ \\
\hline
\end{tabular}

Comparing $\mathrm{Li}$ et $\mathrm{al}^{[7]}$ results, was possible to note a good proximity between conditions in both experiments.

Using cold model, made by acrylic, as shown in Figure 4, the experiments were made at room temperature, using water (as steel), paraffin oil (as slag), washing powder (responsible for create emulsion) and compressed air (as oxygen) ${ }^{[8]}$.

Before running the test, the vessel has water at the height that represents the level of liquid metal and oil mixed with washing powder until the height that represents the level of slag. At the compressed air system outlet the lance tips were connected. To feed the system with compressed air was used a $22.5 \mathrm{~kW}$ compressor, capable of providing a maximum pressure of $7.87 \times 10^{5} \mathrm{~Pa}$ and a maximum flow of $189 \mathrm{~m}^{3} / \mathrm{h}$. The cold model represents a 220 tons converter, corresponding the operation conditions for the relation volume/load of $0,63 \mathrm{~m}^{3} / \mathrm{t}$. The relation consist in division of the converter volume, in cubic meters, with the total scrap/hot metal charged mass. The cold model was made in scale $1 / 8$. 


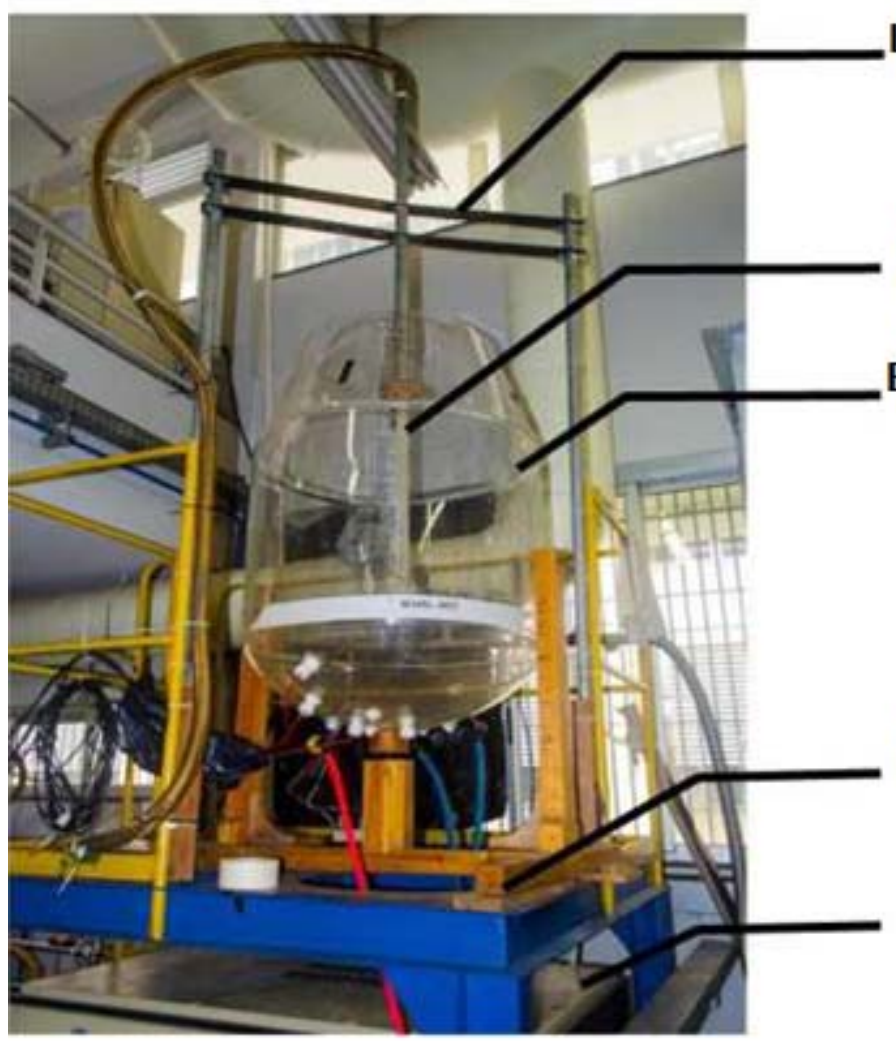

Lance holder

Lance and acrilyc resin nozzle

BOF Converter

Platform

Compressor

Figure 4 - Converter BOF physical model (Lasip - UFMG).

The experiments were made in the Simulation Process Laboratory, localized in the Metallurgical and Materials department (DeMet-UFMG), and conducted with the same flow conditions, using distance bath lance of 0,12 and $0,18 \mathrm{~m}$.

\section{RESULTS AND DISCUSSION}

\subsection{Obtained results by Li et al}

Li et al results are presented in Figure 5.

Results show the increase of distance bath-lance promotes a lower jet penetration on bath assuring good adhesion of obtained results in cold model and numerical simulations. A value deviation observaded in cold model was calculated for $120 \mathrm{~mm}$. The figure 6 shows the oxigen jet behavior causing a cavity in slag layer and with small penetration in metal column. 


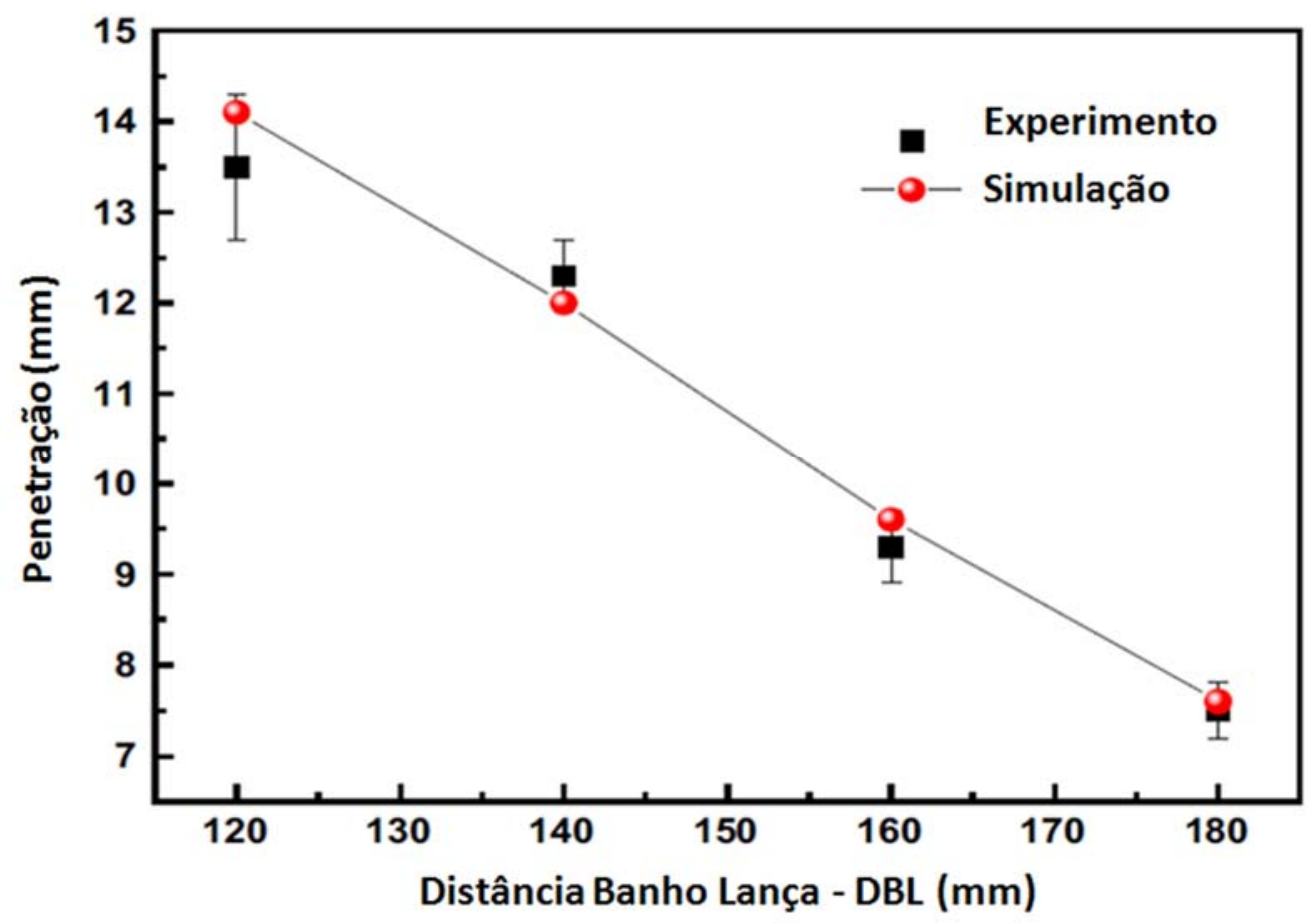

Figure 5- Obtained Results of penetration by Li et al[7].

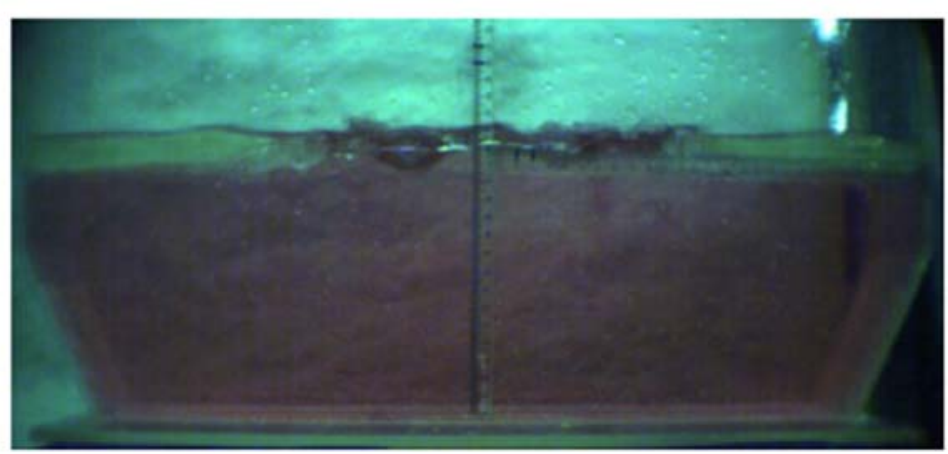

(a)

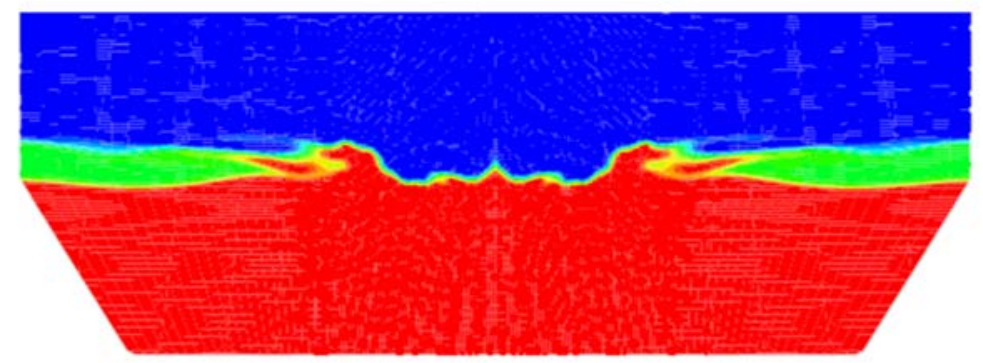

(b)

Figure 6 - Penetration Comparison obtained by Li et al [7]: a) cold model and b) numerical simulation

The figure 7 shows a comparison between the experiments that used just water and the experiments with oil and water. 


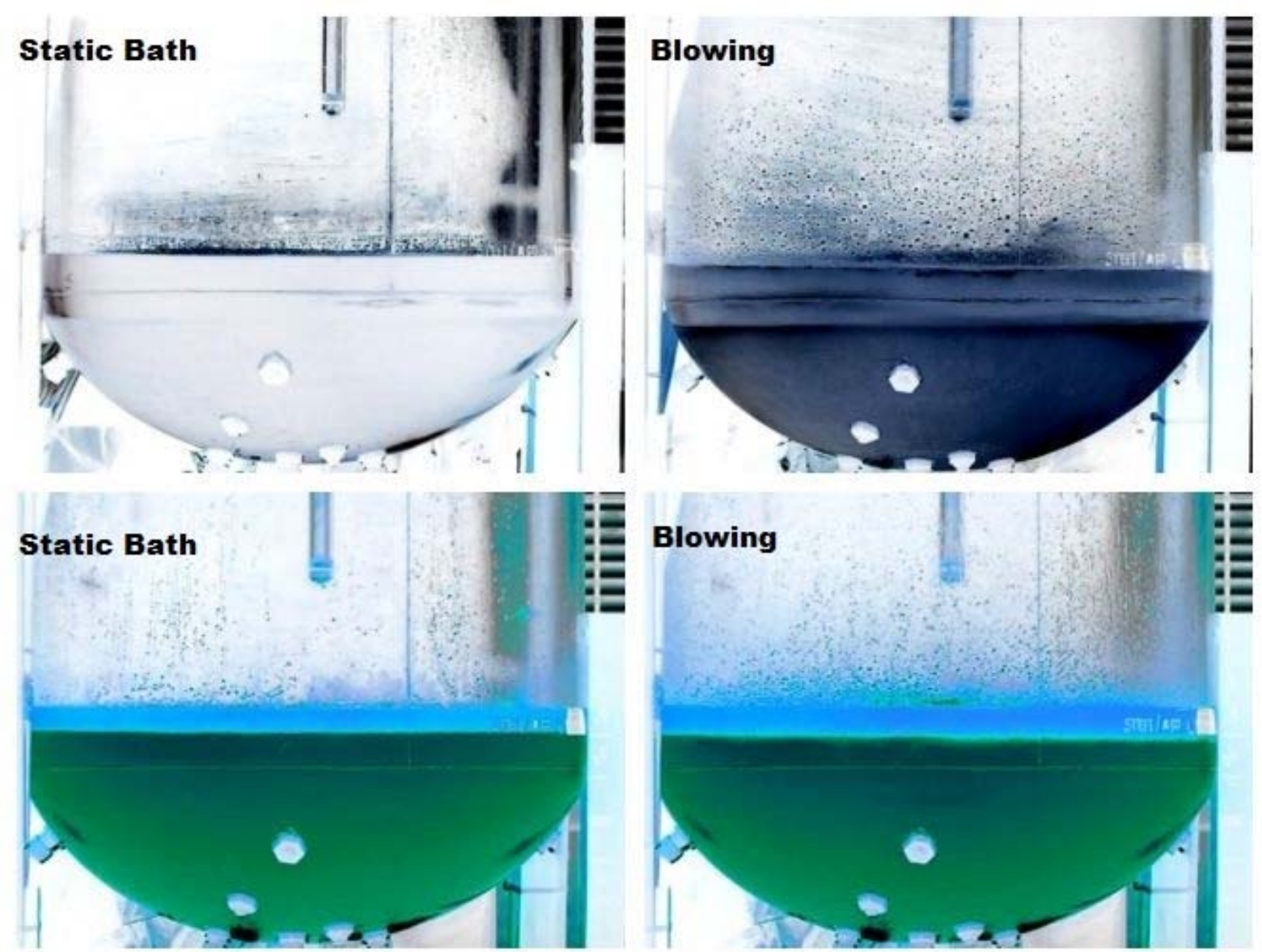

Figure 7 - Comparison between static bath and blowing for two contrast: Upper in shades of Gray and under in shades of blue

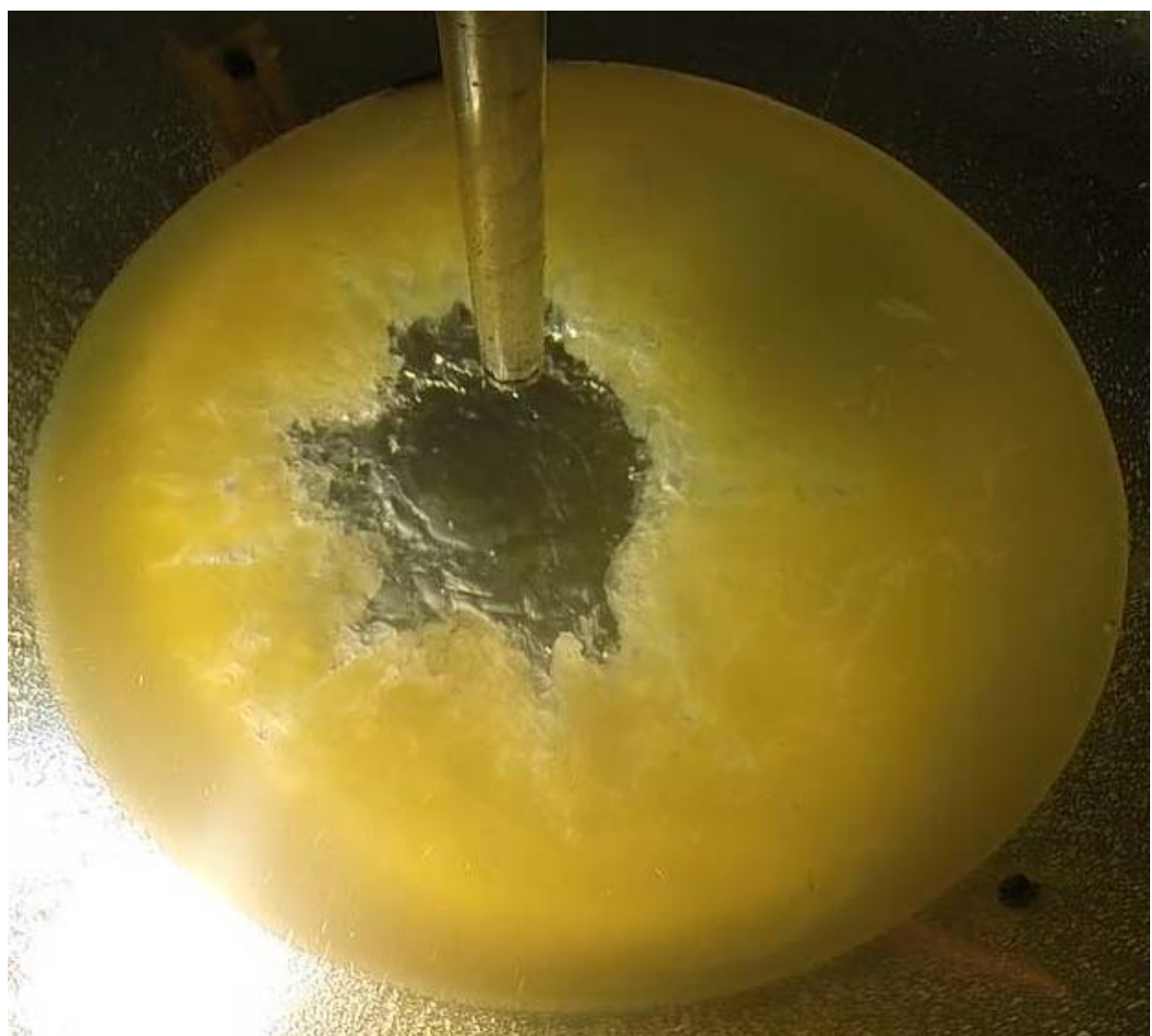

Figure 8 - Top view of Jet penetration in slag and bath layer 
As represented in Figure 7, before the blow is easy to see the interface between slag and metal. During the blow, started the splash generation, mainly in the grey contrast, followed by slight bulging of slag layer. Was possible to note the lower jet penetration in the metallic bath, considering the grey contrasted images. In order to compare Figure 6, that shows jet heating the bath, is possible to note two points: higher slag layer for LaSiP experiments and reactor geometry between studies.

Figure 8 shows top view, where it is possible to see the jet penetrating in slag layer and moving material in radial direction of converter. Its also possible to note that occurs a disturbance of metal bath but with low penetration. Despite the differences between the LaSiP figures and those obtained by $\mathrm{Li}$ et al ${ }^{[7]}$ they also have similar behavior.

Li et al [7] didnt mention the physical characteristics of cold model used in experiments, but the image allows to hypothesize that cold model has a lateral cut in the trunnion area to represent the converter. From the results published by Li et al [7] and using Equation 6, the $\mathrm{K}$ factor was calculated as shown in Figure 9.

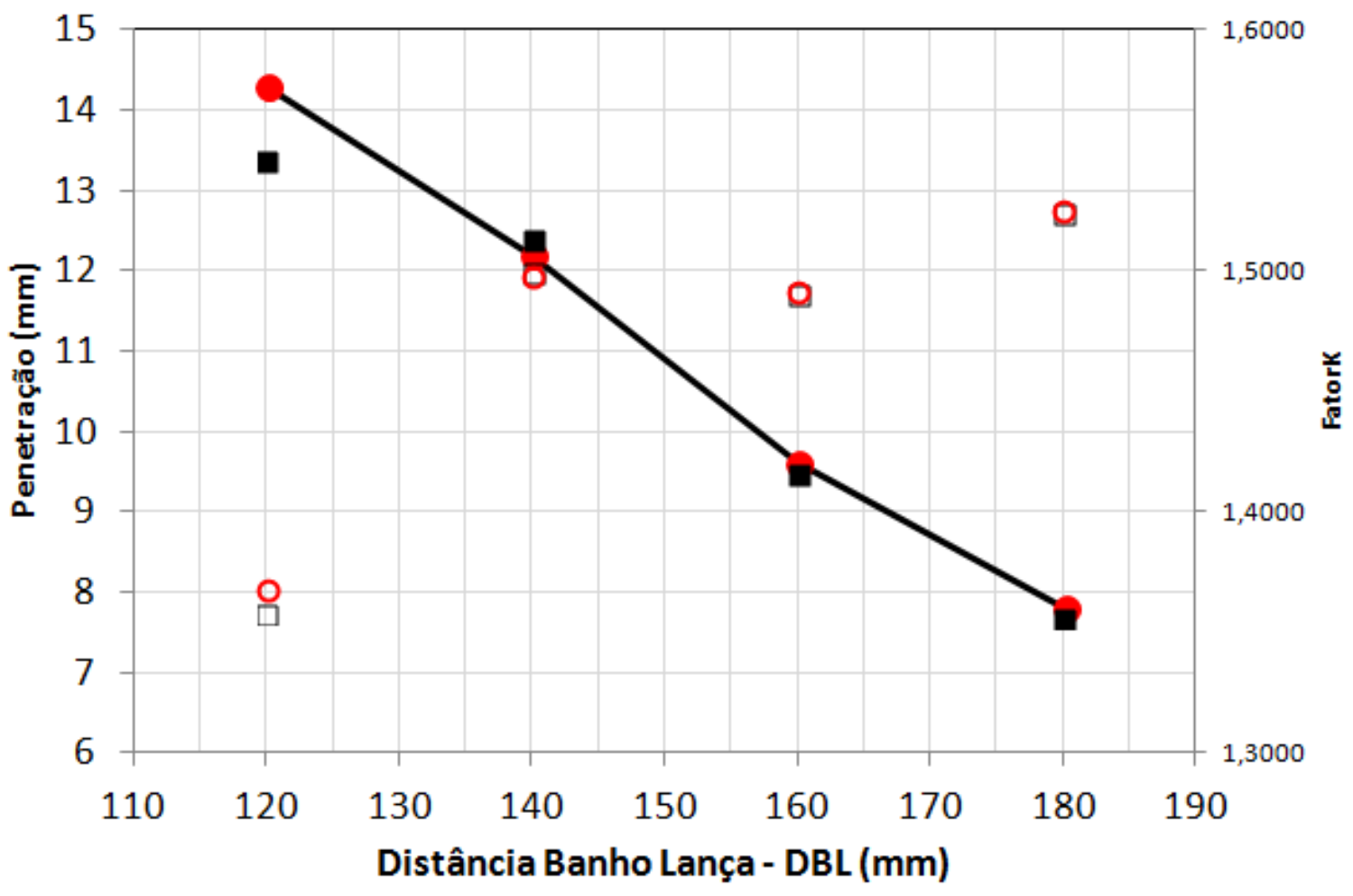

Penetração- Modelo a Frio - - Penetração-simulação

K- modelo a frio

K- simulação

Figure 9 -Calculation of constant $\mathrm{K}$ on basis of results of $\mathrm{Li}$ et al ${ }^{[7]}$

The slag layer has strong influence at factor $\mathrm{K}$ from equation 6 . Compared with other papers $^{[2-6]}, \mathrm{K}$ factor change from units to thousandths. This reduction is function of slag resistance for jet penetration due high surface tension.

\subsection{Results from present paper}

Figure 10 shown values for factor $\mathrm{K}$ found at present work and comparison with $\mathrm{Li}$ et al[ $^{[7]}$ results. 


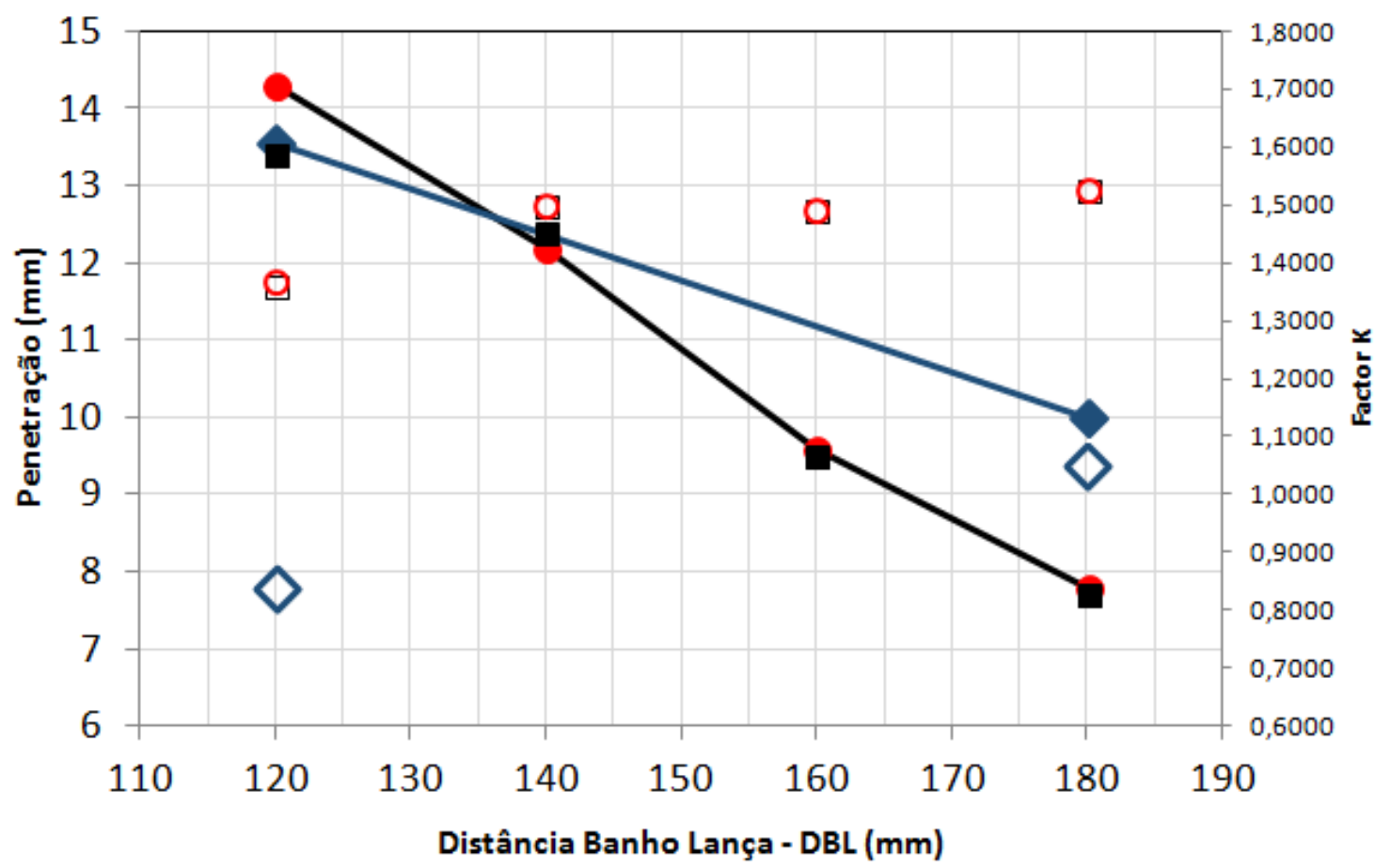

$\begin{array}{lll}\text { - Penetração-modelo a frio } & - \text {-Penetração-simulação } & - \text { Penetração-LaSiP } \\ \square \mathrm{K} \text {-modelo a frio } & \bigcirc \mathrm{K} \text {-simulação } & \diamond \mathrm{K} \text { - LASIP }\end{array}$

Figure 10 - Jet penetration and factor found at present work and comparison with Li et al ${ }^{[7]}$ results.

From figure 10, the results between booth trials are coherent, showed that when increase Distance Bath Lance (DBL), jet penetration decrease. $\mathrm{K}$ factor achieved at LaSIP has same magnitude in comparison with $\mathrm{Li}$ et $\mathrm{al}^{[7]}$ results and good adherence with equation 6 . The values of $\mathrm{K}$ factor shown in figure 10 are considered unique and allow the use in industrial reactors with potential benefits at blowing settings parameters and corrections as a function of slag mass variation along of one blow. The difference of penetration values can be explained by the difference at slag layer thickness, as can be seen in Table I and in uncertain geometric conditions, which represents the converter of comparison papers.

\section{CONCLUSION}

The main conclusions of the study are:

1. Slag has important effect in the interaction jet-metallic bath, decreasing penetration;

2. Penetration values achieved in the present work are similar to $\mathrm{Li}$ et al ${ }^{[7]}$ results;

3. The jet penetration increase inside the slag-metal bath when the bath lance distance decrease;

4. Including slag phase in $\mathrm{K}$ factor, the value changes the order of units to hundredths;

5. The $\mathrm{K}$ factor measured for all experiments shows deviations resulting from the conditions of each experiment, but the values are similar;

6. Including slag phase in the energy balance equation, is possible to predict the jet penetration;

7. The $\mathrm{K}$ factor values are inedited and allow new developments and correction of industrial parameters in real converters. 


\section{Acknowledgments}

The authors thank the Universidade Federal de Minas Gerais for providing the dependencies of Process Simulation Laboratory - UFMG (Lasip) and inputs for the tests and the Lumar Metals by encouraging continued research and support.

\section{REFERENCES}

1 SZEKELY, J. THEMELIS, N. J., Rate Phenomena in Process Metallurgy. 1 ed. Montreal: John Wiley \& Sons, 1971. 784p.

2 MEIDANI, A. R. N., ISAC, M., RICHARDSON, A., CAMERON, A., GUTHRIE, R. I. L. Modeling Shrouded Supersonic Jets in Metallurgical Reactor Vessels. ISIJ International, 2004, v.44, n.10, p. 1639-1645.

3 ALAM, M., IRONS, G., BROOKS, G., FONTANA, A., NASER, J., Inclined Jetting and Splashing in Electric Arc Furnace Steelmaking. ISIJ International, 2011, v.51, n.9, p. 1439-1447.

4 MAIA, B. T., IMAGAWA, R. K., BATISTA, C. J., PETRUCELLI, A. C., TAVARES, R. P. Effects of Blow Parameters in the Jet Penetration by Physical Model of BOF Converter. AISTech 2013 Procedings. Stoughton, 2013. p.2059-2073.

5 MAIA, B. T. FAUSTINO, R. A., ABREU, G., COSTA, B., TAVARES, R. P., Efeitos dos Parâmetros de Sopro no Tempo de Mistura Utilizando Modelo Físico de Convertedor. Anais do $44^{\circ}$ Seminário de Aciaria Internacional, Araxá, Minas Gerais, Maio, 2013.

6 MAIA, B. T., PETRUCELLI, A. C., DINIZ, C. N. A., SILVEIRA, D., ANDRADE, P. H. M. S., IMAGAWA, R. K., TAVARES, R. P., Comparação da Penetração do sopro de Oxigênio em Convertedores BOF com Bicos Multifuros utilizando Modelagem Física. Seminário de Aciaria Internacional. Porto Alegre, Maio 2014.

7 LI, Q., LI, M., KUANG, S., ZOU, Z., Numerical Simulation of the Interaction Between Supersonic Oxygen Jets and Molten Slag-Metal Bath in Steelmaking BOF Process, Metallurgical and Materials Transactions B, v46B, p1494-1509, jun, 2015.

8 BARBOSA, F. A., Modelamento Matemático e Físico do Escoamento do Aço Líquido em Diferentes Projetos de Distribuidor do Lingotamento Contínuo da USIMINAS. Belo Horizonte: Escola de Engenharia da UFMG, 2002. 188p. (Dissertação, Mestrado em Engenharia Metalúrgica). 